\title{
GERHANA MATAHARI DI ABAD 21
}

\author{
Alimuddin \\ Fakultas Syariah dan Hukum UIN Alauddin Makassar
}

\begin{abstract}
:
Solar eclipse is a lesson that the world was created Allah with any regularity. Knowledge of the solar eclipse is a guide to live a life in the calculation time. Is a prediction about the things that will happen in the future. As believers, it is a great lesson to better understand the creation of Allah and can add to the quality of faith.
\end{abstract}

Keywords:

Eclipse of the sun

\begin{abstract}
Abstrak
Gerhana matahari merupakan pelajaran bahwa alam diciptakan Allah Swt dengan segala keteraturannya. Pengetahuan tentang gerhana matahari merupakan petunjuk dalam menjalani kehidupan dalam perhitungan waktu. Merupakan prediksi tentang hal-hal yang akan terjadi di masa yang akan datang. Sebagai orang yang beriman, hal ini merupakan pelajaran besar untuk semakin memahami ciptaan Allah Swt dan dapat menambah kualitas keimanan.
\end{abstract}

Kata Kunci:

Gerhana Matahari

\section{A. PENGERTIAN GERHANA}

erhana adalah peristiwa tertutupnya sebuah objek disebabkan adanya benda/objek yang melintas di depannya. Kedua objek yang terlibat dalam gerhana ini memiliki ukuran yang hampir sama jika diamati dari Bumi. Contoh gerhana Matahari dan gerhana Bulan.

Secara umum, gerhana pada dasarnya ada dua macam yaitu gerhana matahari dan gerhana bulan. Kedua gerhana ini masih mengalami beberapa bentuk menurut proses terjadinya. Dengan demikian baik gerhana matahari maupun gerhana bulan juga terbagi pada beberapa bentuk.

\section{B. PROSES TERJADINYA GERHANA MATAHARI ${ }^{1}$}

Gerhana Matahari terjadi ketika posisi bulan terletak di antara Bumi dan Matahari sehingga menutup sebagian atau seluruh cahaya Matahari. Walaupun

${ }^{1}$ file:///D:/Gerhana\%20matahari\%20-Wikipedia\%20bahasa\%20Indonesia,\%20ensiklopedia\%20bebas.htm 
Bulan lebih kecil, bayangan Bulan mampu melindungi cahaya Matahari sepenuhnya karena Bulan yang berjarak rata-rata jarak 384.400 kilometer dari Bumi lebih dekat dibandingkan Matahari yang mempunyai jarak rata-rata 149.680.000 kilometer.

\section{MACAM-MACAM GERHANA}

Gerhana Matahari dapat dibagi menjadi empat jenis yaitu:

1) Gerhana total terjadi apabila saat puncak gerhana, piringan Matahari ditutup sepenuhnya oleh piringan Bulan. Saat itu, piringan Bulan sama besar atau lebih besar dari piringan Matahari. Ukuran piringan Matahari dan piringan Bulan sendiri berubah-ubah tergantung pada masing-masing jarak Bumi-Bulan dan Bumi-Matahari.

2) Gerhana sebagian terjadi apabila piringan Bulan (saat puncak gerhana) hanya menutup sebagian dari piringan Matahari. Pada gerhana ini, selalu ada bagian dari piringan Matahari yang tidak tertutup oleh piringan Bulan.

3) Gerhana cincin terjadi apabila piringan Bulan (saat puncak gerhana) hanya menutup sebagian dari piringan Matahari. Gerhana jenis ini terjadi bila ukuran piringan Bulan lebih kecil dari piringan Matahari. Sehingga ketika piringan Bulan berada di depan piringan Matahari, tidak seluruh piringan Matahari akan tertutup oleh piringan Bulan. Bagian piringan Matahari yang tidak tertutup oleh piringan Bulan, berada di sekeliling piringan Bulan dan terlihat seperti cincin yang bercahaya.

4) Gerhana hibrida bergeser antara gerhana total dan cincin. Pada titik tertentu di permukaan bumi, gerhana ini muncul sebagai gerhana total, sedangkan pada titik-titik lain muncul sebagai gerhana cincin. Gerhana hibrida relatif jarang.

\section{Gambar Gerhana Matahari}

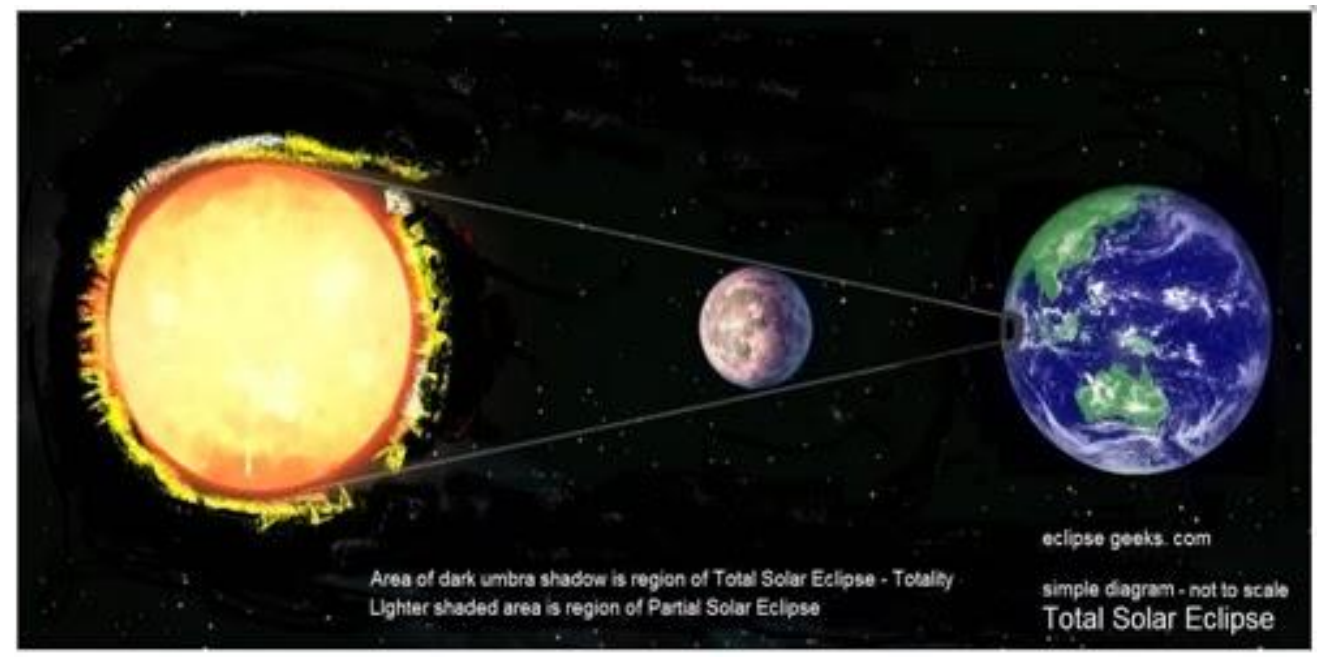

\section{GERHANA PADA MASA NABI MUHAMMAD SAW.}

Secara historis, di zaman Nabi Muhammad Saw. pernah terjadi gerhana matahari dan diriwayatkan dalam beberapa hadis. Hanya saja hadis-hadis tentang 
gerhana tidak merinci waktu terjadinya gerhana. Hal ini mungkin disebabkan lebih berfokus pada aspek tuntunan ibadahnya yakni shalat gerhana ketika terjadi gerhana matahari.

Pada sisi lain, diriwayatkan bahwa putra Rasulullah Saw meninggal pada saat berusia masih kecil pada hari terjadinya gerhana matahari. Beberapa riwayat menyebutkan bahwa ia lahir pada bulan Zulhijjah tahun $8 \mathrm{H}$, namun riwayat itu berbeda menyebutkan usia Ibrahim saat meninggal dunia, ada yang mengatakan 16 bulan, 18 bulan dan ada juga yang mengatakan satu tahun sepuluh bulan atau 22 bulan. Demikian pula hari dan bulannya kelahirannya terjadi perbedaan riwayat. ${ }^{2}$

Di antara hadis yang berkaitan dengan gerhana dan kematian serta usia Ibrahim adalah:

\section{Pertama ;}

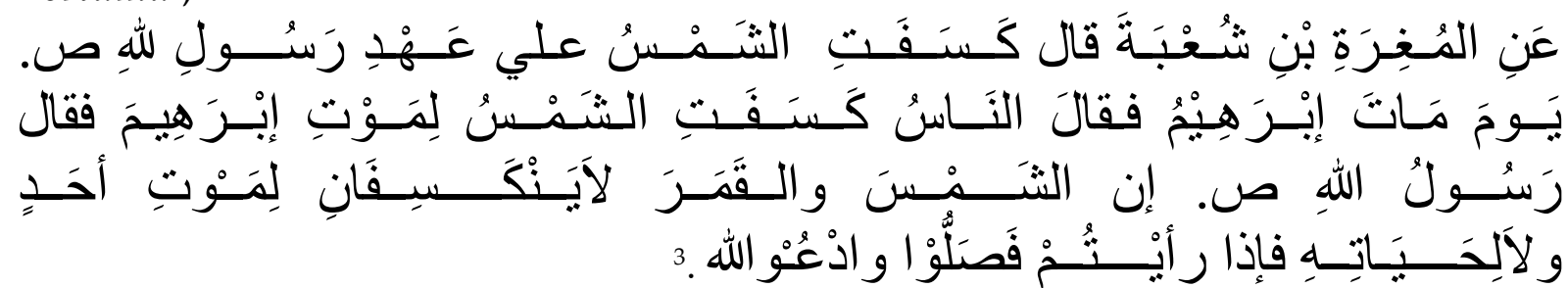

Dari al-Mughirah Ibn Syu'bah (diriwayatkan bahwa) ia berkata ; terjadi gerhana matahari di masa Rasulullah Saw pada hari meninggalnya Ibrahim. Beberapa orang berkata ; gerhana itu terjadi karena kematian Ibrahim. Maka Rasulullah saw bersabda: Sesungguhnya matahari dan bulan tidak gerhana karena mati dan hidupnya seseorang. Jika kamu mengalami (gerhana itu ) kerjakanlah shalat dan berdoalah kepada Allah (HR. Bukhari $)^{4}$

\section{Kedua;}

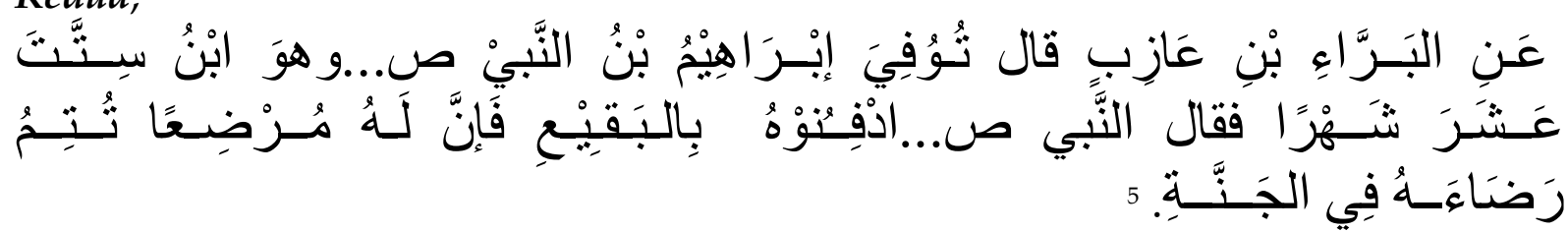

Dari al-Barra Ibn Azib diriwayatkan bahwa ia berkata Ibrahim putra Nabi Saw meninggal ketika berusia 16 bulan, maka Nabi Saw bersabda; "makamlah ia di al-Baqi', ia akan mendaptkan Ibu susu yang akan menyempurnakan susuannya di surga". (HR. Abd. ArRazzaq). ${ }^{6}$

Menurut para ahli gerhana matahari dapat terjadi sekurang-kurangnya dua kali dan maksimal lima kali dalam setahun. Namun ketika terjadi gerhana matahari, tidak'semua tempat di muka bumi dapat menyaksikannya. Hal ini disebabkan karena bayangan pekat bulan (umbra) yang menyebabkan gerhana matahari total

${ }^{2}$ Syamsul Anwar, Interkoneksi Studi Hadis dan Astronomi, Cet. 1; (Jogjakarta : Suara Muhammadiyah, 2011 ), h. 157

${ }^{3}$ Al-Bukhari, Jamiu’Shahih Jilid II ; (al-Qahirah : Dar Sya'ab, 1987/1407), 42.

${ }^{4}$ Syamsul Anwar., h. 160 .

${ }^{5}$ Abd ar-Razzaq, al-Musannaf, edisi Habib ar-Rahman, (Beirut : al-Maktab al-Islami, 1403), h. 494.

${ }^{6}$ Syamsul Anwar.., h. 160-161. 
hanya menutupi satu jalur sempit di muka bumi selebar sekitar 250 KM. Sedangkan bayangan semu bulan (panumbra), meskipun mengenai kawasan muka bumi yang amat luas, namun juga tidak menutupi keseluruhan muka bumi. Gerhana matahari dialami oleh bagian bumi yang tersinari matahari, yaitu bagian bumi yangsedang mengalami siang. Sedangkan bagian bumi yang sedang berada di malam hari tidak mengalami gerhana karena ia tidak menghadap ke matahari. ${ }^{7}$

Menurut perhitungan secara astronomi (Solar Eclipse Explorer-NASA) diketahui bahwa selama periode risalah Nabi Saw di Mekkah dan Madinah (13 SH s/d $11 \mathrm{H}$ ), telah terjadi 8 kali gerhana matahari yang dapat dilihat dari kota Mekkah dan kota Madinah. Empat kali gerhana matahari selama periode Mekkah dan empat kali selama periode Madinah. Data-data gerhana matahari dimaksud adalah sebagai berikut:

a) Periode Mekkah (610-622 M);

Selama periode Mekkah gerhana matahari terjadi sebanyak empat kali, yaitu ;

1. Tahun $613 \mathrm{M}$.

Pada tahun ini gerhana matahari terjadi pada hari senin, tanggal 23 Juli $613 \mathrm{M}$ atau bertepatan 29 Ramadhan $10 \mathrm{SH}$. Mulai gerhana pukul 07:03:05 waktu Mekkah, gerhana maksimum pukul 08:12:20 WM, akhir gerhana pukul 09:32:11 WM. dan tipe gerhana adalah "sebagian".

2. Tahun $616 \mathrm{M}$

Gerhana matahari terjadi pada hari Jumat tanggal 21 Mei $616 \mathrm{M}$ atau bertepatan 29 Sya'ban 7 SH. Mulai gerhana terjadi pada pukul 07:12:05 WM. Gerhana Maksimum pukul 08:25:01 WM, akhir gerhana pukul 09:51:43 WM dan tipe gerhana "sebagian".

3. Tahun $617 \mathrm{M}$

Gerhana matahari terjadi pada hari Jumat 04 November 617 M bertepatan dengan 29 shafar 5 SH. Gerhana terjadi mulai pukul 08:47:41 WM, Gerhana Maksimum terjadi pukul 10:19:46 WM. Akhir gerhana pada pukul 12:06:36 WM dan tipe gerhana matahari adalah "sebagian"

4. Tahun $620 \mathrm{M}$

Tahun $620 \mathrm{M}$, gerhana matahari terjadi pada hari selasa tanggal 02 September $620 \mathrm{M}$, bertepatan dengan tanggal 29 Muharram 2 SH. Mulai gerhana pukul 07:06: 08 WM, gerhana maksimum pukul 08:10:18 WM dan ahkir gerhana pada pukul 09:22:57 WM. Adapun tipe gerhana adalah juga "sebagian"

b) Periode Madinah ( 622 s/d 632 M)

Pada periode ini gerhana matahari terjadi juga sebanyak empat kali, yaitu ;

1. Tahun $624 \mathrm{M}$

Pada tahun 624 M, gerhana matahari terjadi pada hari Kamis, 21 Juni 624 M,

${ }^{7}$ Syamsul Anwar., h. 169 . 
bertepatan dengan 29 Zulhijjah 2 H. Gerhana mulai pukul 18:42:48 Waktu Madinah, gerhana maksimum pukul 19:08 WMd. , akhir gerhana pukul 19:08 WMd. Dan tipe gerhana adalah "sebagian".

2. Tahun $627 \mathrm{M}$

Pada tahun ini gerhana matahari terjadi pada hari Selasa tanggal 21 April $627 \mathrm{M}$ (29 Zulqaidah $5 \mathrm{H}$ ). Mulai gerhana pada pukul 10:32:15 WMd., gerhana maksimum pada pukul 10:57:24 WMd. Akhir gerhana pada pukul 11:22:57 WMd. Tipe gerhana matahari adalah "sebagian"

3. Tahun $628 \mathrm{M}$

Gerhana terjadi pada hari Senin, tanggal 03 Oktober 628 M (29 Jumadil Awal 7 H). Mulai gerhana pada pukul 06:18 (terbit) WMd. Gerhana Maksimum pukul 06:28:02 WMd. Dan akhir gerhana adalah pukul 06:58:13 WMd. Tipe gerhana matahari adalah "sebagian"

4. Tahun $632 \mathrm{M}$

Gerhana matahari terjadi pada hari senin tanggal 27 Januari 632 M (29 syawal 10 H). Gerhana mulai terjadi pukul 07:15:57 WMd., gerhana maksimum pukul 08 : 29: 14 WMd., dan akhir gerhana adalah pukul 09 :54: 29 WMd. Tipe gerhana adalah "sebagian" 8

\section{E. PERISTIWA GERHANA MATAHARI DI ABAD $21 \mathrm{M}$}

Di kalangan para ahli astronomi, dan dengan dukungan kemajuan ilmu pengetahuan dan teknologi, telah diperhitungan secara astronomi, bahwa akan terjadi sebanyak 224 kejadian gerhana Matahari pada abad ke-21, yang sedikit di bawah rata-rata kejadian dalam seabad (238 kejadian per satu abad). ${ }^{11}$

Berikut ini dilihat data-data gerhana Matahari dari segi tanggal, waktu, jenis gerhana dan jalur daerah wilayah kejadiannya hingga lima puluh tahun yang akan datang (tahun 2001 hingga 2049 ) ${ }^{9}$ sebagai berikut :

$\begin{array}{cccccccc}\text { Tanggal } & \text { Pukul } & \text { Jenis } & \text { Saros Gamma Ukuran Lamanya } & \begin{array}{c}\text { Lebar } \\ \text { jalur }\end{array} \\ \begin{array}{c}21 \text { Juni } \\ 2001\end{array} & 12: 04: 46 & \text { Total } & 127 & -0,570 & 1,050 & 04 \mathrm{~m} 57 \mathrm{~s} & 200 \text { Afrika } \\ \begin{array}{c}14 \\ \begin{array}{c}\text { Desember } \\ \text { 20:53:01 Cincin }\end{array}\end{array} & 132 & +0,409 & 0,968 & 03 \mathrm{~m} 53 \mathrm{~s} & 126 \text { Amerika tengah }\end{array}$

${ }^{8}$ Ibid., h. 170-172, bandingkan http://usmaniy.wordpress.com/2012/05/09/gerhana-matahari-pada-zamanrasulullah/, di donwloud, 11 Maret 2014

${ }^{9}$ Sumber ; http://id.wikipedia.org/wiki/Daftar_gerhana_matahari, 13 juni 2014 


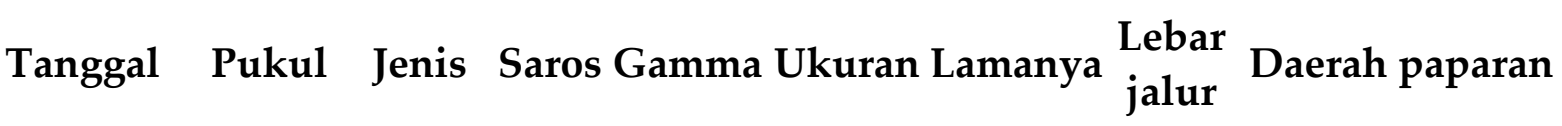
2001

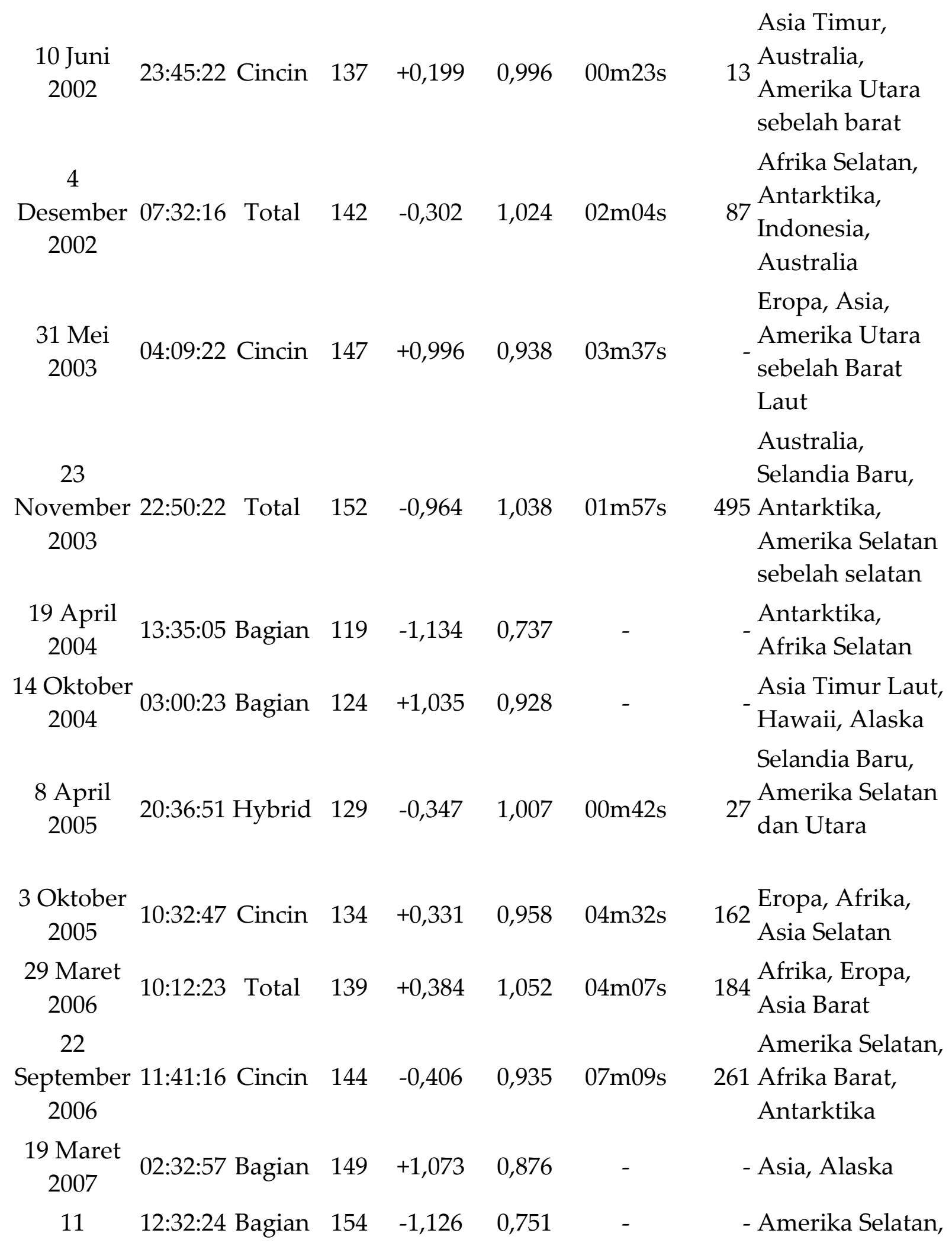




\begin{tabular}{|c|c|c|c|c|c|c|c|c|}
\hline Tanggal & Pukul & Jenis & Saros & Gamma & Ukuran & Lamanya & $\begin{array}{l}\text { Lebar } \\
\text { jalur }\end{array}$ & Daerah paparan \\
\hline $\begin{array}{l}\text { September } \\
2007\end{array}$ & & & & & & & & Antarktika \\
\hline $\begin{array}{l}7 \text { Februari } \\
2008\end{array}$ & 03:56:10 & Cincin & 121 & $-0,957$ & 0,965 & $02 \mathrm{~m} 12 \mathrm{~s}$ & 444 & $\begin{array}{l}\text { Antarktika, } \\
\text { Australia Timur, } \\
\text { Selandia Baru }\end{array}$ \\
\hline $\begin{array}{l}1 \text { Agustus } \\
2008\end{array}$ & $10: 22: 12$ & Total & 126 & $+0,831$ & 1,039 & $02 \mathrm{~m} 27 \mathrm{~s}$ & 237 & $\begin{array}{l}\text { Amerika Utara } \\
\text { sebelah timur } \\
\text { laut, Eropa, Asia }\end{array}$ \\
\hline$\frac{26 \text { Januari }}{\underline{2009}}$ & $07: 59: 45$ & Cincin & 131 & $-0,282$ & 0,928 & $07 \mathrm{~m} 54 \mathrm{~s}$ & 280 & $\begin{array}{l}\text { Afrika Selatan, } \\
\text { Antarktika, Asia } \\
\text { sebelah } \\
\text { tenggara, } \\
\text { Australia }\end{array}$ \\
\hline$\frac{22 \text { Juli }}{\underline{2009}}$ & $02: 36: 25$ & Total & 136 & $+0,070$ & 1,080 & 06m39s & 258 & $\begin{array}{l}\text { Asia Timur, } \\
\text { Pasifik, Hawaii }\end{array}$ \\
\hline $\begin{array}{l}15 \text { Januari } \\
2010\end{array}$ & 07:07:39 & Cincin & 141 & $+0,400$ & 0,919 & $11 \mathrm{~m} 08 \mathrm{~s}$ & 333 & $\begin{array}{l}\text { Afrika, Asia, } \\
\text { Indonesia GMS }\end{array}$ \\
\hline $\begin{array}{l}11 \text { Juli } \\
2010\end{array}$ & $19: 34: 38$ & Total & 146 & $-0,679$ & 1,058 & $05 \mathrm{~m} 20 \mathrm{~s}$ & 259 & $\begin{array}{l}\text { Amerika Selatan } \\
\text { sebelah selatan }\end{array}$ \\
\hline 4.1.2011 & $08: 51: 42$ & Bagian & 151 & $+1,063$ & 0,858 & - & & $\begin{array}{l}\text { Eropa, Afrika, } \\
\text { Asia Tengah }\end{array}$ \\
\hline 1.6.2011 & $21: 17: 18$ & Bagian & 118 & $+1,213$ & 0,601 & - & & $\begin{array}{l}\text { Asia Timur, } \\
\text { Amerika Utara } \\
\text { sebelah utara, } \\
\text { Island }\end{array}$ \\
\hline 1.7.2011 & 08:39:30 & Bagian & 156 & $-1,492$ & 0,097 & - & & $\begin{array}{l}\text { Samudra Hindia } \\
\text { sebelah selatan }\end{array}$ \\
\hline 25.11.2011 & $06: 21: 24$ & Bagian & 123 & $-1,054$ & 0,905 & - & & $\begin{array}{l}\text { Afrika Selatan, } \\
\text { Antarktika, } \\
\text { Tasmanien, } \\
\text { Selandia Baru }\end{array}$ \\
\hline 20.5.2012 & $23: 53: 54$ & Cincin & 128 & $+0,483$ & 0,944 & $05 \mathrm{~m} 46 \mathrm{~s}$ & 237 & $\begin{array}{l}\text { Asia, Pasifik, } \\
\text { Amerika Utara }\end{array}$ \\
\hline 13.11.2012 & 22:12:55 & Total & 133 & $-0,372$ & 1,050 & $04 \mathrm{m02s}$ & 179 & $\begin{array}{l}\text { Australia, } \\
\text { Selandia Baru, } \\
\text { Pasifik Selatan, }\end{array}$ \\
\hline
\end{tabular}


Tanggal Pukul Jenis Saros Gamma Ukuran Lamanya $\begin{aligned} & \text { Lebar } \\ & \text { jalur }\end{aligned}$

Amerika Selatan sebelah selatan

Australia,

10.5.2013 00:26:20 Cincin $138 \quad-0,269 \quad 0,954 \quad 06 \mathrm{~m} 03 \mathrm{~s}$

3.11.2013 12:47:36 Hybrid $143+0,327 \quad 1,016 \quad 01 \mathrm{~m} 40$ s

29.4.2014 06:04:33 Cincin $148 \quad-1,000 \quad 0,987$

23.10.2014 21:45:39 Bagian $153+1,091 \quad 0,811$

173 Selandia Baru, Pasifik Tengah

Amerika Selatan dan Utara

58 sebelah timur, Eropa Selatan, Afrika

Samudra Hindia sebelah selatan, Australia, Antarktika Pasifik Utara, Amerika Utara Pulau Faroe, 20.3.2015 09:46:47 Total $120 \quad+0,945 \quad 1,045 \quad 02 \mathrm{~m} 47 \mathrm{~s} \quad 463 \begin{aligned} & \text { Eropa, Afrika } \\ & \text { Utara, Asia }\end{aligned}$ Utara Afrika Selatan, Samudra Hindia 13.9.2015 06:55:19 Bagian $125 \quad-1,100 \quad 0,787 \quad-\quad$ - $\quad$ sebelah selatan, Antarktika

9.3.2016 01:58:19 Total $130 \quad+0,261 \quad 1,045 \quad 04 \mathrm{~m} 09 \mathrm{~s}$ 155 Asia Timur, Australia, Pasifik

1.9.2016 09:08:02 Cincin $135 \quad-0,333 \quad 0,974 \quad$ 03m06s 100 Afrika, Samudra Amerika Selatan 26.2.2017 14:54:33 Cincin $140 \quad-0,458 \quad 0,992 \quad 00 \mathrm{~m} 44 \mathrm{~s}$ 31 sebelah selatan, Atlantik, Afrika, Antarktika Amerika Utara,

$\underline{21.8 .2017}$ 18:26:40 Total $145 \quad+0,437 \quad 1,031 \quad 02 \mathrm{~m} 40 \mathrm{~s}$

15.2.2018 20:52:33 Bagian $150 \quad-1,212 \quad 0,599 \quad$ 115 Amerika Selatan sebelah utara Antarktika, Amerika Selatan 
Tanggal Pukul Jenis Saros Gamma Ukuran Lamanya

\begin{tabular}{|c|c|c|c|c|c|}
\hline 13.7.2018 & 03:02:16 Bagian & 117 & $-1,354$ & 0,337 & - \\
\hline 11.8.2018 & 09:47:28 Bagian & 155 & $+1,148$ & 0,737 & - \\
\hline 6.1 .2019 & 01:42:38 Bagian & 122 & $+1,142$ & 0,715 & - \\
\hline 2.7.2019 & 19:24:07 Total & 127 & $-0,647$ & 1,046 & $04 \mathrm{~m} 33 \mathrm{~s}$ \\
\hline 26.12.2019 & 05:18:53 Cincin & 132 & $+0,414$ & 0,970 & $03 \mathrm{~m} 40 \mathrm{~s}$ \\
\hline 21.6.2020 & 06:41:15 Cincin & 137 & $+0,121$ & 0,994 & $00 \mathrm{~m} 38 \mathrm{~s}$ \\
\hline
\end{tabular}

$\begin{array}{llllll}\text { 14.12.2020 16:14:39 Total } & 142 & -0,294 & 1,025 & 02 \mathrm{~m} 10 \mathrm{~s}\end{array}$

10.6.2021 10:43:07 Cincin $147 \quad+0,915 \quad 0,943 \quad 03 \mathrm{~m} 51 \mathrm{~s}$

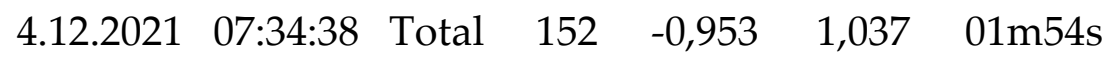

30.4.2022 20:42:36 Bagian $119 \quad-1,190 \quad 0,640$

25.10.2022 11:01:20 Bagian $124+1,070 \quad 0,862$

(1)

20.4.2023 04:17:56 Hybrid $129 \quad-0,395 \quad 1,013 \quad 01 \mathrm{~m} 16 \mathrm{~s}$

\section{Lebar} jalur

Daerah paparan sebelah selatan

- Australia Selatan Eropa Utara,

- Asia Timur Laut Asia Timur Laut, - Pasifik Utara

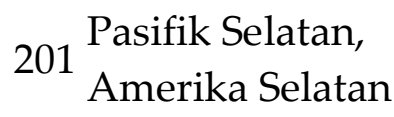
118 Asia, Australia Afrika, Eropa 21 sebelah tenggara, Asia Pasifik, Amerika $90 \begin{aligned} & \text { Selatan sebelah } \\ & \text { selatan, }\end{aligned}$ Antarktika Amerika Utara 527 sebelah utara, Eropa, Asia Antarktika, 419 Afrika Selatan, Atlantik Selatan Pasifik sebelah tenggara, Amerika Selatan sebelah selatan Eropa, Afrika Timur Laut, - Naher Osten, Asia Barat Asia sebelah tenggara, Asia 49 Tenggara, Philippinen. Selandia Baru 


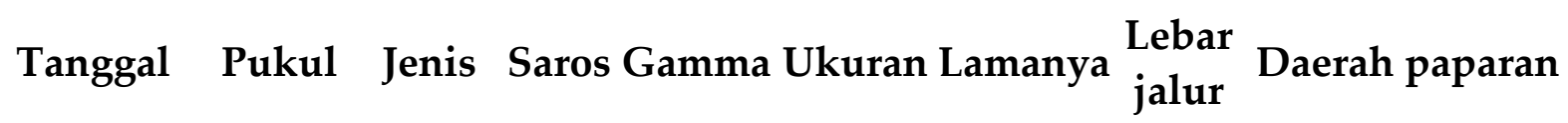
Amerika Utara,

14.10.2023 18:00:41 Cincin $134 \quad+0,375 \quad 0,952 \quad 05 \mathrm{~m} 17 \mathrm{~s} \quad{ }_{187}^{\text {Amerika }} \begin{aligned} & \text { Tengah, } \\ & \text { Tenah }\end{aligned}$ Amerika Selatan

8.4.2024 18:18:29 Total $139+0,343 \quad 1,057 \quad 04 \mathrm{~m} 28 \mathrm{~s} \quad 198 \begin{aligned} & \text { Amerika Utara, } \\ & \text { Amerika Tengah }\end{aligned}$ Pasifik, Amerika

2.10.2024 18:46:13 Cincin $144 \quad-0,351 \quad 0,933 \quad 07 \mathrm{~m} 25 \mathrm{~s} \quad$ 266 Selatan sebelah selatan

Afrika Barat

29.3.2025 10:48:36 Bagian $149+1,041 \quad 0,938 \quad-\quad$ - Laut, Eropa, Rusia Utara Pasifik Selatan,

21.9.2025 19:43:04 Bagian $154 \quad-1,065 \quad 0,855 \quad$ - $\quad$ - Selandia Baru, Antarktika

Chili dan Argentina

17.2.2026 12:13:06 Cincin $121 \quad-0,974 \quad 0,963 \quad 02 \mathrm{~m} 20 \mathrm{~s} \quad 616$ selatan, Afrika Selatan, Antarktika Amerika Utara

12.8.2026 17:47:06 Total $126 \quad+0,898 \quad 1,039 \quad 02 \mathrm{~m} 18 \mathrm{~s}$ 294 sebelah utara, Eropa

Amerika Selatan,

6.2.2027 16:00:48 Cincin $131 \quad-0,295 \quad 0,928 \quad 07 \mathrm{~m} 51 \mathrm{~s}$ 282 Antarktika, Afrika Selatan dan Barat Afrika, Eropa, 2.8.2027 10:07:50 Total $136+0,142 \quad 1,079 \quad 06 \mathrm{~m} 23 \mathrm{~s} \quad 258$ Naher Osten, Asia Selatan dan Barat Amerika Utara sebelah timur, 26.1.2028 15:08:59 Cincin $141+0,390 \quad 0,921 \quad 10 \mathrm{~m} 27 \mathrm{~s}$ 323 Amerika Selatan dan Tengah, Eropa Barat, 
Tanggal Pukul Jenis Saros Gamma Ukuran Lamanya $\begin{aligned} & \text { Lebar } \\ & \text { jalur }\end{aligned}$

\begin{tabular}{|c|c|c|c|c|c|c|}
\hline & & & & & & $\begin{array}{l}\text { Afrika Barat } \\
\text { Laut }\end{array}$ \\
\hline 22.7.2028 & 02:56:40 Total & 146 & $-0,606$ & 1,056 & $05 \mathrm{~m} 10 \mathrm{~s}$ & $\begin{array}{l}\text { Asia Tenggara, } \\
\text { Asia Tenggara, } \\
\text { Australia, } \\
\text { Selandia Baru }\end{array}$ \\
\hline 14.1.2029 & 17:13:48 Bagian & 151 & $+1,055$ & 0,871 & - & $\begin{array}{l}\text { Amerika Utara, } \\
\text { Amerika Tengah }\end{array}$ \\
\hline 12.6 .2029 & 04:06:13 Bagian & 118 & $+1,294$ & 0,458 & - & $\begin{array}{l}\text { Arktik, } \\
\text { Skandinavia, } \\
\text { - Alaska, Asia } \\
\text { Utara, Kanada } \\
\text { Utara }\end{array}$ \\
\hline 11.7.2029 & 15:37:19 Bagian & 156 & $-1,419$ & 0,230 & - & $\begin{array}{l}\text { Chili dan } \\
\text { - Argentina } \\
\text { selatan }\end{array}$ \\
\hline 5.12 .2029 & 15:03:58 Bagian & 123 & $-1,061$ & 0,891 & - & $\begin{array}{l}\text { Chili dan } \\
\text { Argentina } \\
\text { selatan, } \\
\text { Antarktika }\end{array}$ \\
\hline 1.6.2030 & 06:29:13 Cincin & 128 & $+0,563$ & 0,944 & $05 \mathrm{~m} 21 \mathrm{~s}$ & $\begin{array}{l}\text { Eropa, Afrika } \\
\text { Utara, Naher } \\
250 \text { Osten, Asia, } \\
\text { Arktik, Alaska }\end{array}$ \\
\hline 25.11.2030 & 06:51:37 Total & 133 & $-0,387$ & 1,047 & $03 \mathrm{~m} 44 \mathrm{~s}$ & $\begin{array}{l}\text { Afrika Selatan, } \\
\text { Samudra Hindia } \\
\text { sebelah selatan, } \\
\text { Asia Tenggara, } \\
\text { Australia, } \\
\text { Antarktika }\end{array}$ \\
\hline 21.5.2031 & 07:16:04 Cincin & 138 & $-0,197$ & 0,959 & $05 \mathrm{~m} 26 \mathrm{~s}$ & $\begin{array}{l}\text { Afrika, Asia } \\
\text { Selatan, Asia } \\
152 \text { Tenggara, } \\
\text { Australia }\end{array}$ \\
\hline 14.11.2031 & 21:07:31 Hybrid & 143 & $+0,308$ & 1,011 & $01 \mathrm{~m} 08 \mathrm{~s}$ & $\begin{array}{l}\text { Pasifik, Amerika } \\
38 \text { Serikat sebelah } \\
\text { selatan, Amerika }\end{array}$ \\
\hline
\end{tabular}


Tanggal Pukul Jenis Saros Gamma Ukuran Lamanya $\begin{aligned} & \text { Lebar } \\ & \text { jalur }\end{aligned}$

Tengah,

Amerika Selatan sebelah Barat

Laut

Amerika Selatan

9.5.2032 13:26:42 Cincin $148 \quad-0,938 \quad 0,996 \quad 00 \mathrm{~m} 22 \mathrm{~s}$ 44 sebelah selatan, Afrika Selatan

3.11.2032 05:34:13 Bagian $153 \quad+1,064 \quad 0,855 \quad$ - $\quad$ - Asia

30.3.2033 18:02:36 Total $120+0,978 \quad 1,046 \quad 02 \mathrm{~m} 37 \mathrm{~s}$

781 Amerika Utara

$\begin{array}{llllllc}\text { 23.9.2033 } & 13: 54: 31 \text { Bagian } 125 & -1,158 & 0,689 & - \\ & & & & & & \\ \text { 20.3.2034 } & 10: 18: 45 & \text { Total } & 130 & +0,289 & 1,046 & 04 \mathrm{~m} 09 \mathrm{~s}\end{array}$

Amerika Selatan

- sebelah selatan, Antarktika

159 Afrika, Eropa, Asia Barat

Amerika

12.9.2034 16:19:28 Cincin $135 \quad-0,394 \quad 0,974 \quad$ 02m58s 102 Tengah, Amerika Selatan

Australia, Selandia Baru,

9.3.2035 23:05:54 Cincin $\quad 140 \quad-0,437 \quad 0,992 \quad 00 \mathrm{~m} 48 \mathrm{~s}$ 31 Pasifik Selatan, Meksiko, Antarktika

2.9.2035 01:56:46 Total $145 \quad+0,373 \quad 1,032 \quad 02 \mathrm{~m} 54 \mathrm{~s}$ 116 Asia Timur,
Pasifik Antarktika,

27.2.2036 04:46:49 Bagian $150 \quad-1,194 \quad 0,629 \quad \ldots \quad$ Australia - Selatan, Selandia Baru

23.7.2036 10:32:06 Bagian $117 \quad-1,425 \quad 0,199 \quad-$

21.8.2036 17:25:45 Bagian $155+1,083 \quad 0,862$

- Atlantik Selatan Alaska, Kanada, Arktik, Eropa Barat, Afrika Barat Laut Afrika Utara, 16.1.2037 09:48:55 Bagian $122 \quad+1,148 \quad$ 0,705 - - $\quad$ - Eropa, Naher Osten, Asia 


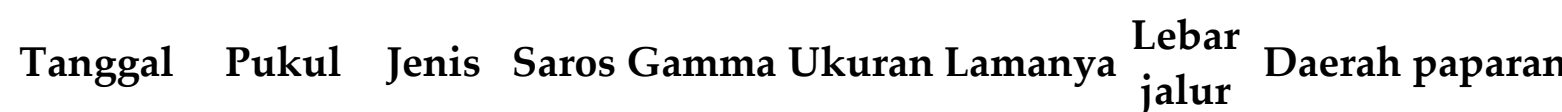

\begin{tabular}{|c|c|c|c|c|c|c|c|}
\hline & & & & & & & Barat \\
\hline 13.7.2037 & $02: 40: 36$ & Total & 127 & $-0,725$ & 1,041 & $03 \mathrm{~m} 58 \mathrm{~s}$ & $\begin{array}{l}\text { Asia Tenggara, } \\
\text { Australia, Pasifik }\end{array}$ \\
\hline 5.1.2038 & $13: 47: 11$ & Cincin & 132 & $+0,417$ & 0,973 & $03 \mathrm{~m} 18 \mathrm{~s}$ & $\begin{array}{l}\text { Amerika Utara } \\
\text { sebelah timur, } \\
\text { Amerika Selatan } \\
\text { sebelah utara, } \\
\text { Atlantik, Afrika, } \\
\text { Eropa }\end{array}$ \\
\hline 2.7.2038 & 13:32:55 & Cincin & 137 & $+0,040$ & 0,991 & 01m00s & $\begin{array}{l}\text { Amerika Tengah } \\
\text { dan Utara, } \\
31 \text { Amerika Selatan, } \\
\text { Afrika, Eropa, } \\
\text { Naher Osten }\end{array}$ \\
\hline 26.12.2038 & 01:00:10 & Total & 142 & $-0,288$ & 1,027 & $02 \mathrm{~m} 18 \mathrm{~s}$ & $\begin{array}{l}\text { Asia sebelah } \\
\text { tenggara, Asia } \\
\text { Tenggara, } \\
95 \text { Australia, } \\
\text { Selandia Baru, } \\
\text { Pasifik Selatan, } \\
\text { Antarktika }\end{array}$ \\
\hline 21.6.2039 & $17: 12: 54$ & Cincin & 147 & $+0,831$ & 0,945 & $04 \mathrm{~m} 05 \mathrm{~s}$ & $\begin{array}{l}\text { Amerika Utara, } \\
\text { Eropa Barat }\end{array}$ \\
\hline 15.12.2039 & $16: 23: 46$ & Total & 152 & $-0,946$ & 1,036 & 01m51s & $\begin{array}{l}\text { Amerika Selatan } \\
380 \text { sebelah selatan, } \\
\text { Antarktika }\end{array}$ \\
\hline 11.5 .2040 & 03:43:02 & Bagian & 119 & $-1,253$ & 0,531 & - & $\begin{array}{l}\text { Australia, } \\
\text { - Selandia Baru, } \\
\text { Antarktika }\end{array}$ \\
\hline 4.11.2040 & 19:09:02 & Bagian & 124 & $+1,099$ & 0,807 & - & $\begin{array}{l}\text { Amerika Tengah } \\
\text { dan Utara }\end{array}$ \\
\hline 30.4 .2041 & $11: 52: 21$ & Total & 129 & $-0,449$ & 1,019 & 01m51s & $\begin{array}{l}72 \text { Brasil, Afrika, } \\
\text { Naher Osten }\end{array}$ \\
\hline 25.10 .2041 & $01: 36: 22$ & Cincin & 134 & $+0,413$ & 0,947 & $06 \mathrm{~m} 07 \mathrm{~s}$ & $213 \begin{array}{l}\text { Asia Timur, } \\
\text { Pasifik }\end{array}$ \\
\hline 20.4.2042 & 02:17:30 & Total & 139 & $+0,296$ & 1,061 & $04 \mathrm{~m} 51 \mathrm{~s}$ & $210 \begin{array}{l}\text { Asia Timur, Asia } \\
\text { sebelah }\end{array}$ \\
\hline
\end{tabular}


Tanggal Pukul Jenis Saros Gamma Ukuran Lamanya $\begin{aligned} & \text { Lebar } \\ & \text { jalur }\end{aligned}$

tenggara,

Australia, Pasifik

Asia sebelah

tenggara, Asia

14.10.2042 02:00:42 Cincin $144 \quad-0,303 \quad 0,930 \quad 07 \mathrm{~m} 44 \mathrm{~s}$

9.4.2043 18:57:49 Total $149+1,003 \quad 1,010$

Tenggara,

Australia, Pasifik

Selatan,

Antarktika

Amerika Utara

- sebelah utara,

Asia Timur Laut

Antarktika,

3.10.2043 03:01:49 Cincin $154 \quad-1,010 \quad 0,950$

Australia Barat

- Daya, Samudra

Hindia

28.2.2044 20:24:39 Cincin $121 \quad-0,995 \quad 0,960 \quad 02 \mathrm{~m} 27 \mathrm{~s}$

Antarktika,

Amerika Selatan

Asia Utara,

23.8.2044 01:17:02 Total $126 \quad+0,961 \quad 1,036 \quad 02 \mathrm{~m} 04 \mathrm{~s}$

453 Amerika Utara sebelah barat,

Tanah Hijau

Australia,

16.2.2045 23:56:07 Cincin $131 \quad-0,313 \quad 0,928 \quad 07 \mathrm{~m} 47 \mathrm{~s} \quad$ 281 Selandia Baru,

Pasifik, Hawaii

Amerika Tengah

12.8.2045 17:42:39 Total $136 \quad+0,212 \quad 1,077 \quad 06 \mathrm{~m} 06 \mathrm{~s}$

256 dan Utara,

Amerika Selatan,

Afrika Barat

Australia, Papua

5.2.2046 23:06:26 Cincin $141+0,377 \quad 0,923 \quad 09 \mathrm{~m} 42 \mathrm{~s} \quad 310$ Nugini, Amerika Serikat sebelah

barat

2.8.2046 10:21:13 Total $146 \quad-0,535 \quad 1,053 \quad 04 \mathrm{~m} 51 \mathrm{~s}$

206 Brasil, Afrika

26.1.2047 01:33:18 Bagian $151+1,045 \quad 0,891$

Asia Timur,

Alaska

23.6.2047 10:52:31 Bagian $118+1,377 \quad 0,313$

Kanada Utara,

- Tanah Hijau, 
Tanggal Pukul Jenis Saros Gamma Ukuran Lamanya $\begin{gathered}\text { Lebar } \\ \text { jalur }\end{gathered}$

\begin{tabular}{|c|c|c|c|c|c|c|}
\hline & & & & & & Asia Timur Laut \\
\hline 22.7.2047 & 22:36:17 Bagian & 156 & $-1,348$ & 0,360 & - & $\begin{array}{l}\text { Australia } \\
\text { sebelah } \\
\text { tenggara, } \\
\text { Selandia Baru }\end{array}$ \\
\hline 16.12.2047 & 23:50:12 Bagian & 123 & $-1,066$ & 0,882 & - & $\begin{array}{l}\text { Antarktika, Chili } \\
\text { - dan Argentina } \\
\text { selatan }\end{array}$ \\
\hline 11.6.2048 & 12:58:53 Cincin & 128 & $+0,647$ & 0,944 & $04 \mathrm{~m} 58 \mathrm{~s}$ & $\begin{array}{l}\text { Amerika Utara, } \\
\text { Karibik, Afrika } \\
272 \text { Utara, Eropa, } \\
\text { Asia Barat }\end{array}$ \\
\hline 5.12 .2048 & 15:35:27 Total & 133 & $-0,397$ & 1,044 & $03 \mathrm{~m} 28 \mathrm{~s}$ & $\begin{array}{l}\text { Amerika Selatan } \\
\text { sebelah selatan, } \\
\text { Afrika Selatan } \\
\text { Barat }\end{array}$ \\
\hline 31.5.2049 & 13:59:59 Cincin & 138 & $-0,119$ & 0,963 & $04 \mathrm{~m} 45 \mathrm{~s}$ & $\begin{array}{l}\text { Amerika Serikat } \\
\text { sebelah } \\
\text { tenggara, } \\
\text { Amerika Tengah }\end{array}$ \\
\hline
\end{tabular}

Demikianlah data-data gerhana matahari yang akan terjadi di abad 21 prespektif astronomi-ilmu pengetahuan dan teknologi. Gambaran gerhana matahari ini memberikan pelajaran bahwa alam di ciptakan Allah Swt dengan segala keteraturannya, dapat ,menjadi pelajaran dan petunjuk dalam menjalani kehidupan ini dalam perhitungan waktu akan hal-hal yang akan terjadi di masa-masa yang akan datang. Sebagai orang yang beriman hal seperti ini, merupakan pelajaran besar untuk semakin memahami kesempurnaan ciptaan Allah Swt, dan dapat menambah kwalitas keimanan. 


\section{Daftar Pustaka}

Ichtiyanto. Almanak Hisab Rukyat, Jakarta : Badan Hisab Rukyat Departemen Agama RI., 1981.

Jamil, A. Ilmu Falak (Teori dan Aplikasi). Cet. 1 ; Jakarta : Sinar Grafika Offset, 2009.

KH. Shaleh, dkk., Asbabun Nuzul. Cet. 9; Bandung : CV. Diponegoro, 1987

Khazin, Muhyiddin. Cara Mudah Mengukur Arah Kiblat, Cet. I; Jogjakarta : Buana Pustaka, 2004.

ILmu Falak dalam Teori dan Aplikasi, Cet. 1; Yogyakarta : Buana Pustaka, 2004.

150 Tahun(1925-2075) Kalender Masehi Hijriyah. Cet. II; Jogjakarta :

Buana Pustaka,

Kementerian Agama RI., Ephemeris Hisab Rukyat 2012. Jakarta : Direktorat Urusan

Agama Islam dan Pembinaan Syariah Ditjen Bimbingan Masyarakat Islam, 2012.

Mukarram, Akh. Ilmu Falak Dasar-Dasar Hisab Praktis. Cet. I; Surabaya : Grafika Media, 2012.

Muchtar dan Fatchurrahman, Dasar-Dasar Pembinaan Hukum Fikih Islam, Cet.III; Bandung: al-Ma'arif,199

Majelis Ulama Indonesia Kota Makassar ; Makassar : Fatwa-fatwa Majelis Ulama Indonesia Kota Makassar, 2009

Musthafa Kamal Pasha dan Ahmad Adaby Darbau, Muhammadiyah sebagai Gerakan Islam, Cet.1; Yogyakarta : Citra Karsa Mandiri, 2005

Padil, Abbas., Alimuddin. Ilmu Falak (Dasar-Dasar Ilmu Falak, Masalah arah Kiblat, Waktu Shalat dan Petunjuk Prkatikum). Cet. I; Makassar : Alauddin University Press, 2012.

Parman, Ali. Ilmu Falak, Makassar : Yayasan Ahkam, 2011

Penuntun Praktikum Falak. Makassar : Berkah Utami, 2010.

Purwanto, Agus. Ayat-ayat Semesta; sisi-sisi Al-Qur'an yang terlupakan. Cet. I; Bandung : Mizan, 1429 H / 2008 M.

Pimpinan Pusat. Muhammadiyah, Himpunan Putusan Tarjih Pimpinan Pusat Muhammadiyah Majelis Tarjih, Cet. III; Jogjakarta : Suara`Muhammadiyah, 2009. . Muhammadiyah. Pedoman Hisab Muhammadiyah. Cet. I; Jogjakarta : Majelis Tarjih dan Tajdid PP. Muhammadiyah, 2009.

Shihab, M.Quraish. Tafsir al-Misbah, Vol. 6, Cet. 5 ; Jakarta : Lentera Hati, 2002.

Supriatna, Encup. Hisab Rukyat dan Aplikasinya. Buku Satu, Cet. I; Bandung : Anggota IKAPI, 2007.

Sugiono, Metodologi Penelitian Administrasi dilengkapi dengan Metode $R$ dan D. Cet.XVI ; Bandung : Alfabeta, 2003.

S. Nasution, Metode Research, (Penelitian Ilmiah). Jakarta : Bumi Aksara, 2006.

Tim Penyusun Pustaka, Leksikon Islam. Cet. I; Jakarta: Pustaka Azet, 1988,Jilid I.

Wahbah Az-zuhaili, Fiqih Islam wa Adillatuhu, Jilid 2, Cet. 1 ; terjemahan oleh Abdul 
Hayyie al-Kattani, dkk. Jakarta : Gema Insani, 2010.

Wardan, KR. Muhammad., Kitab Falak dan Hisab, Cet. I; Jogjakarta : Kitab Pandu, 1957 . ILmu Falak dalam Teori dan Aplikasi, Cet. 1; Yogyakarta : Buana Pustaka, 2004.

Kementerian Agama RI., Ephemeris Hisab Rukyat 2012. Jakarta : Direktorat Urusan Agama Islam dan Pembinaan Syariah Ditjen Bimbingan Masyarakat Islam, 2012.

Mukarram, Akh. Ilmu Falak Dasar-Dasar Hisab Praktis. Cet. I; Surabaya : Grafika Media, 2012.

Muhammad Jawad Mughniyah, al-Figh ala Madzahib al-Khamzah, terjemahan oleh Masykur As, dkk.,dengan judul ; Fikih Lima Mazhab, Cet. 16; Jakarta : Lentera Hati, 2006

Nugraha, G. Setya. Kamus Bahasa Indonesia Praktis. Surabaya : Sulita Jaya, 20138. 